\title{
ANCIENT EGYPTIANS IN LITHUANIA: A SCIENTIFIC STUDY OF THE EGYPTIAN MUMMIES AT THE NATIONAL MUSEUM OF LITHUANIA AND THE MK ČIURLIONIS NATIONAL MUSEUM OF ART
}

Dario Piombino-Mascali ${ }^{1}$, Lidija McKnight ${ }^{2}$, Rimantas JankaUsKas ${ }^{1}$

${ }^{1}$ Faculty of Medicine, Vilnius University, Vilnius, Lithuania

${ }^{2} \mathrm{KNH}$ Centre for Biomedical Egyptology,

University of Manchester, Manchester, UK

\begin{abstract}
Since 2011, ancient Egyptian mummified human remains from collections in Lithuania have been subjected to scientific analysis in an attempt to assess the lives and deaths of the individuals, and how their bodies were treated after death in order to achieve bodily preservation. In total, six mummies were studied using computed tomography to obtain the maximum amount of useful data in a non-invasive manner. This paper outlines the aims of the research, what has been done to date and the plans for future work on this corpus of material.
\end{abstract}

Keywords: mummies, CT, Egyptology, Lithuania

\section{INTRODUCTION}

Since 2011, the samples of human mummies present in Lithuania were subjected to systematic survey and biomedical investigations aimed at providing precious information on the lives, lifestyles, health conditions and biological features of ancient preserved bodies through the application of non-destructive radiologic techniques (1). 
Research carried out between 2011 and 2013 made it possible to extend the "Lithuanian Mummy Project" to contain additional individuals from ancient Egypt, from the collection held at the National Museum of Lithuania, Vilnius, and the MK Čiurlionis National Museum of Art, Kaunas.

With the exception of plain radiography conducted on two specimens in 2000 and later labelled as pseudo-mummies (7), no scientific research had ever been performed on these ancient bodies. Such research will allow for an important contribution to the discipline of Egyptology to be made.

Inspired by previous projects on Egyptian mummies carried out since the 1970 s $(3,5,6,8)$, this research will rely upon computed tomography as the best non-invasive technique for the investigation of preserved remains.

The continuing study of Egypt mummies in Lithuania involves a qualified inter-disciplinary research team, which, beyond museum officials, comprises Lithuanian, British and German institutions including the Department of Anatomy, Histology and Anthropology (Vilnius University), the Department of History (Vytautas Magnus University), the KNH Centre for Biomedical Egyptology (University of Manchester), the Reiss-Engelhorn-Museen, and the Department of Radiology (Trauma Center, Murnau).

\section{Historical background}

In 1855, an archaeological commission established the Museum of Antiquities in Vilnius. This first public museum in the country was located in former university rooms. Artefacts from ancient Egypt were collected beginning in 1856. The exhibition of a sarcophagus in 1861 excited huge public interest (Fig. 1). In 1867, the Museum of Antiquities became connected to Vilnius Public Library. During World War I, a number of artefacts were sent to Russia, and others were subsequently lost during the German occupation (16).

In the interbellum period, two museums - the Museum of Archaeology and one for Ethnography - were established in Stefan Batory University. In 1941, the ancient Egyptian collection moved to the Museum of History of the Academy of Sciences (16).

Until 1967, Egypt antiquities were housed in buildings belonging to Vilnius University. Later, they were transported into the Museum of History and Ethnography, which, in 1997, became the Lithuanian National Museum (16).

Another important collection of Egyptian artefacts in Lithuania is held at the National Museum of Art, founded in 1921 and dedicated to composer and artist Mikalojus Konstantinas Čiurlionis. This collection includes antiquities assembled by Marija Rudzinskaitè-Arcimavičienè, the first Lithuanian professional Egyptologist, who bequeathed her private artefacts to the museum (15). 


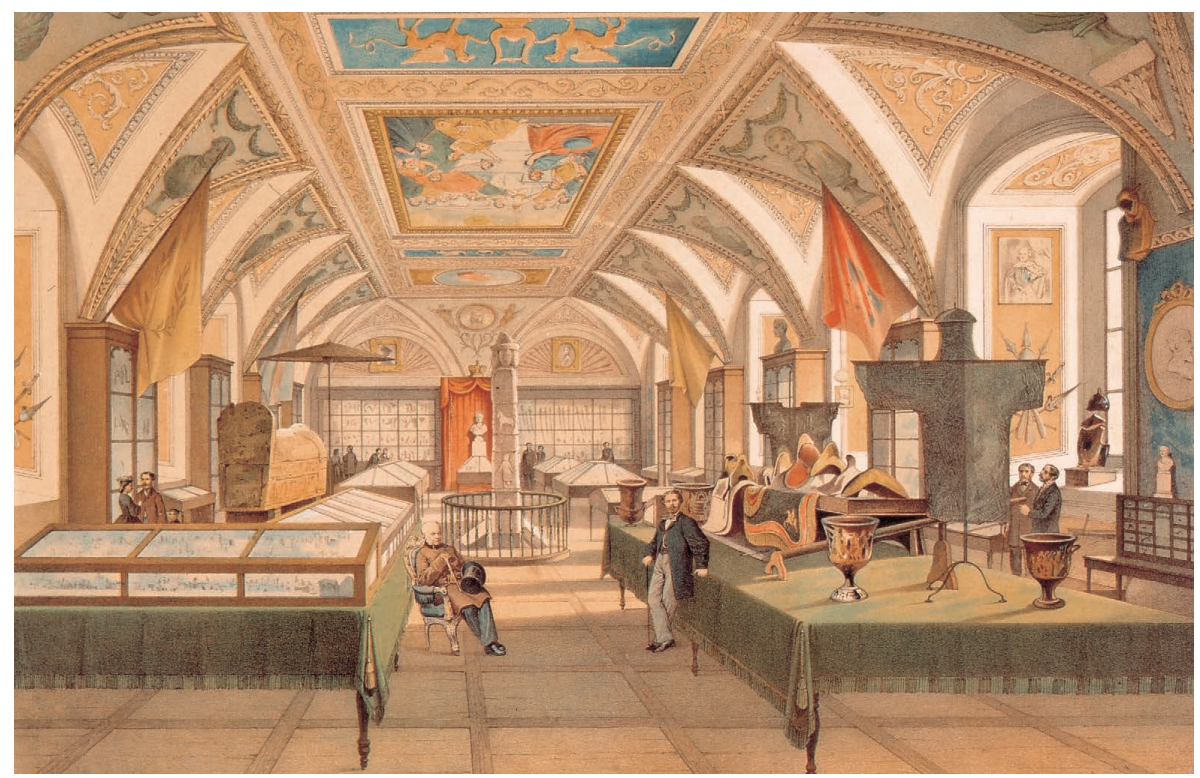

Figure 1. The Museum of Antiquities of Vilnius by Albert Zamett. Chromo-lithograph from Jan Kazimierz Wilczyński's Vilnius Album. Image courtesy of the National Museum of Lithuania.

\section{MATERIALS}

In total, the National Museum of Lithuania curates two child mummies, three adult mummies, and an isolated mummified human head. The materials and their related accession number are briefly described as follows.

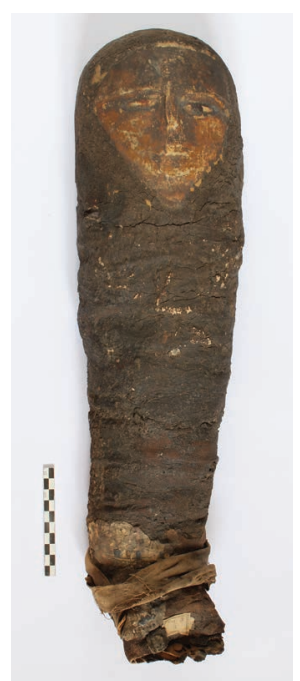

- Child mummy (catalogue number IM - 6286), length $54 \mathrm{~cm}$. The mummy was donated to the Museum of Antiquities in Vilnius by Michał Tyszkiewicz in 1862. The mummy is believed to be a $19^{\text {th }}$ century fake (Fig. 2). Computed tomography (CT) was conducted in Vilnius in 2013.

Figure 2. Pseudo-mummy from the National Museum of Lithuania. Image courtesy of the National Museum of Lithuania. 


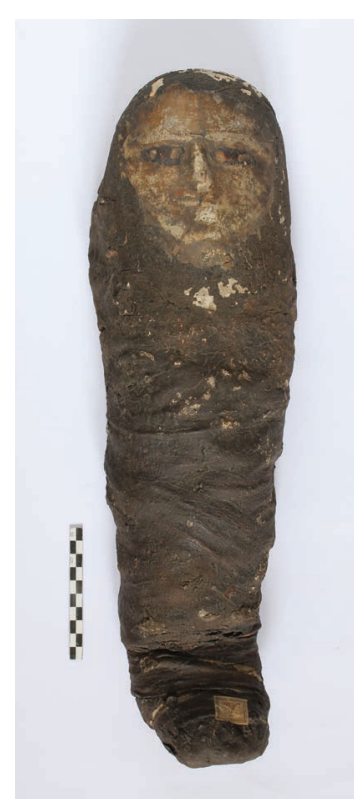

- Child mummy (catalogue number IM - 6287), length $49 \mathrm{~cm}$. The mummy was donated to the Museum of Antiquities in Vilnius by Michał Tyszkiewicz in 1862 . The mummy, like the one previously described, is believed to be a $19^{\text {th }}$ century fake (Fig. 3). The artefact is on loan to the MK Čiurlionis National Museum of Art, and it was CT-scanned in Kaunas in 2013.

Figure 3. An additional pseudo-mummy from the National Museum of Lithuania. Image courtesy of the National Museum of Lithuania.

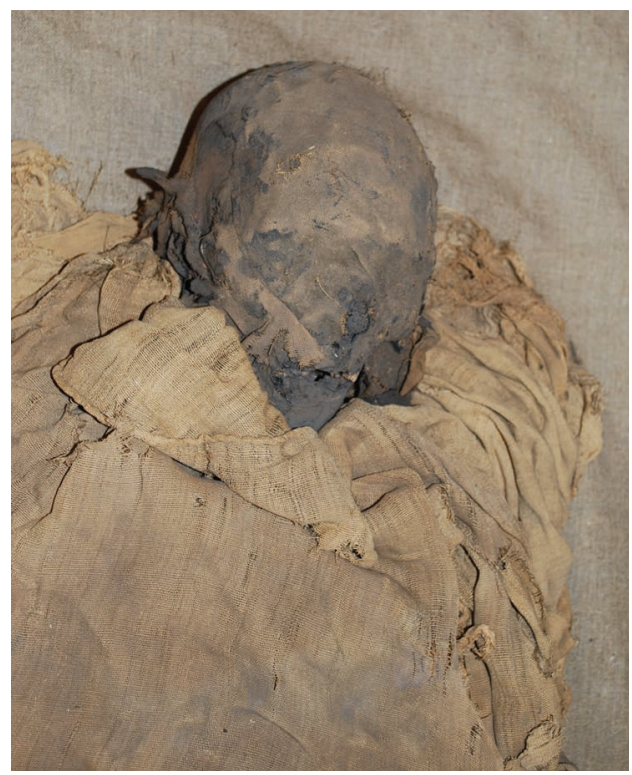

- Mummy with sarcophagus (catalogue number IM - 6283), $183 \times 61.5 \times 56 \mathrm{~cm}$. The mummy was donated to the Museum of Antiquities in Vilnius by Chlodwig Hohenlohe in 1898 (Fig 4). CT was conducted in Vilnius in 2013.

Figure 4. A mummy associated with a sarcophagus, currently housed in the National Museum of Lithuania, Vilnius. Image courtesy of the National Museum of Lithuania. 
- Mummy with sarcophagus (catalogue number IM - 6284), 184x51x42.5 $\mathrm{cm}$. The mummy was donated to the Museum of Antiquities in Vilnius by Chlodwig Hohenlohe in 1898. CT was conducted in Vilnius in 2013.

- Mummy with sarcophagus and inside cover. Thebes, $21^{\text {th }}$ dynasty (catalogue number IM - 6285). The mummy was donated to the Museum of Antiquities in Vilnius by Aleksander Branicki in 1861. CT was conducted in Vilnius in 2013.

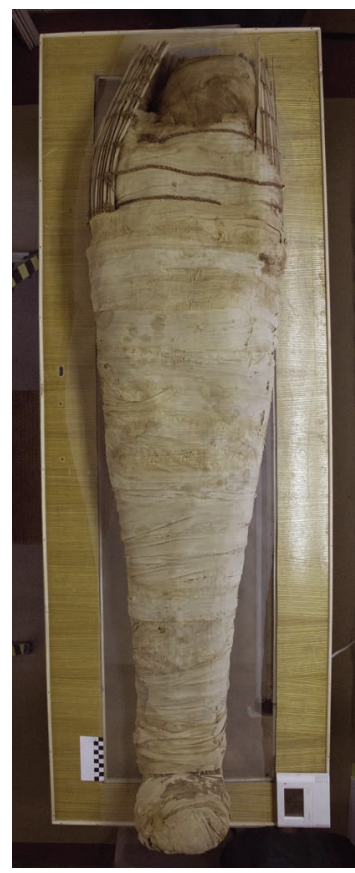

- Mummified human head (catalogue number KT 123).

An additional mummy associated with a sarcophagus (catalogue number - Tt 2797 and Tt 2798), measuring about $187 \times 29 \times 50 \mathrm{~cm}$, dated to the $21^{\text {th }}$ dynasty, was donated by Marija RudzinskaitèArcimavičiene to the Kaunas National Museum of Art, where it remains today (Fig. 5). The bundle was CT-scanned in 2011, whilst in Vilnius for conservation treatment.

Figure 5. The Kaunas mummy. Image courtesy of the Lithuanian Art Museum, Pranas Gudynas Restoration Center.

\section{METHODS AND AIMS OF THE PROJECT}

As previously mentioned, CT was conducted on the six mummies. The first Egyptian specimen to be scanned was an adult male mummy studied in Kaunas, during the time that it was stored in Vilnius for conservation purposes. The subject was examined in 2011 at the Central Branch of the Vilnius University Hospital. A further CT session took place in 2013 at the Vilnius Medea Clinic during which four mummies were studied, while the last specimen, a pseudomummy currently exposed in Kaunas, was scanned in the same year at the Department of Radiology, Lithuanian University of Health Sciences.

$\mathrm{CT}$ is considered to be the best non-invasive imaging technique for the study of mummified remains as it provides a wide range of data which can be used 
to explain details regarding the life, death and treatment of the individuals (1). This technique represents a significant development in radiologic investigation, as it eliminates superimposition and the juxtaposition of elements posed by two-dimensional imaging modalities (11).

The method, which was first carried out on mummified remains in the late 1970s, was soon improved by increasing computing power, which allowed for a finer resolution and the rapid 3D visualisation of images (12). With CT-scanners the X-ray tube revolves around the mummy under investigation, and generates hundreds or thousands of slices as an array of pixels, the value of which depends on the attenuation of the X-rays as they pass through the subject. Thereafter, slices can be combined to obtain three-dimensional reconstructions of the artefacts. Furthermore, a quantitative scale called Hounsfield Unit (HU) scale is used for describing radio-density, discriminating structures and assessing the presence of foreign objects through a scale of gray shades (11).

CT images can also be post-processed through the use of computer programs, which allow the images to be maximised, thus enabling increased visualisation of structures. Colours can also be assigned to specific densities and can form the basis for $3 \mathrm{D}$ rendering. However, as mummified tissues differ greatly from those of the living due to taphonomic changes exerted on the tissues, the process of structure delineation is complicated (17).

Radiological examination of the Lithuanian mummies has produced a vast amount of data which will be examined over the coming months. The mummies will be sexed by viewing the pelvic and cranial morphology as well as the post-cranial robusticity, according to widely accepted protocols employed in archaeology and forensic science (4). Accordingly, ageing will be performed, where possible, by looking at the stage of bone and teeth development and morphological changes of the ox coxae (e.g. pubic symphisis and the auricular surface in disarticulated examples), while stature in life will be measured from the complete bodies as well as from the long bone measurements (4).

Finally, pathological conditions affecting both bone and soft tissues will be investigated. Palaeopathology, the study of ancient disease, has a long tradition in Europe and Lithuania (2). It is a field of growing interest for archaeologists, anthropologists and physicians. Although reconstructing health in the past poses many challenges, some conditions leave evidence on both skeletal and soft tissue $(1,13)$. The most commonly demonstrated conditions consist of infectious and metabolic diseases, degenerative disorders, congenital anomalies and malformations, dental disease, trauma, as well as tumours and tumour-like processes (13). 
Beyond the biomedical information of these subjects, this study will explore the techniques used to prepare and preserve the body (9). It is believed that anthropogenic mummification in ancient Egypt was reserved for the most affluent members of the society, and was extended to a wider demographic in the Graeco-Roman Period (9). Therefore, this study will allow us to investigate the socio-economic status of the deceased, based on the embalming method employed. We will consider evidence for incisions, stuffing materials and cavity packing, along with the inclusion of amulets and adornments, which may be present within the wrappings. Emphasis shall be put on any variability observed in mortuary treatment, comparing our data to those published in the literature $(10,14,18)$. The application of radiological techniques to mummified materials enables an insight into the contents of wrapped bundles and within preserved bodies themselves without the need to disrupt their integrity. This is an important quality when working with archaeological specimens. Radiological data can identify areas of interest, which can be targeted using focused sampling strategies, enabling the maximum amount of information to be gained through minimally-invasive endoscopic methods (1).

In conclusions, the data gathered through this project will be made available to both specialists and the general public, with the release of scientific articles, conferences and a public exhibition.

\section{REFERENCES}

1 Aufderheide A.C. (2003). The Scientific Study of Mummies. Cambridge University Press. Cambridge.

2 Buikstra J., Roberts C. (2012). The Global History of Paleopathology: Pioneers and Prospects. Oxford University Press. Oxford.

3 David A.R. (1979). The Manchester Museum Mummy Project. Manchester University Press. Manchester.

4 DiGangi E.A., Moore M.K. (2013). Research methods in human skeletal biology. Academic Press. London.

5 Figueiredo A. (2005). The Lisbon Mummy Project: the employment of nondestructive methods in mummy studies. In: Piquette K., Love S. (eds), Current Research in Egyptology 2003 - Proceedings of the Fourth Annual Symposium, University College London 2003. Oxbow Books. Oxford, 29-40.

6 Figueiredo A., Owens L.S., Oswald R. (2002). Egyptian mummies at the Museu Nacional de Arqueologia, Lisbon: a proposed programme of study. Papers from the Institute of Archaeology, 13, 101-105.

7 Germer R., Kischkewitz H., Lüning M. (1994). Pseudo-mumien der ägyptischen Sammlung Berlin. SAK, 21, 81-94. 
8 Giuffra V., Pangoli D., Cosmacini P., Caramella D., Silvano F., Fornaciari G., Ciranni R. (2009). Paleopathological evaluation and radiological study of 46 Egyptian mummified specimens in Italian museums. EVO, 32, 121-155.

9 Ikram S., Dodson A. (1998). The mummy in ancient Egypt. AUC Press. Cairo.

10 Lösch S., Rüttiman D., Jackowski C., Küffer A. (2013). Investigations on an Egyptian coffin and mummified head from Burgdorf Museum, Switzerland a case of a historical puzzle. Bulletin der Schweizerischen Gesellschaft für Anthropologie, 19(1), 15-21.

11 Lynnerup N. (2007). Mummies. Yrbk Phys Anthropol, 45, 162-190.

12 Lynnerup N. (2010). Medical imaging of mummies and bog bodies. Gerontology, 56, 441-448.

13 Ortner D.J. (2003). Identification of pathological conditions in human skeletal remains. $2^{\text {nd }}$ edition. Academic Press. San Diego.

14 Saleem S.N., Hawass Z. (2014). Multidetector computer tomographic study of amulets, jewelry, and other foreign objects in Royal Egyptian Mummies dated from the $18^{\text {th }}$ to $20^{\text {th }}$ Dynasties. JCAT, 38(2), 153-158.

15 Snitkuvienè A. (2009). Marija Rudzinskaitè-Arcimavičienës contribution to Egyptology. Acta Orientalia Vilnensia, 10 (1-2), 181-207.

16 Snitkuvienè A. (2011). Lietuva ir senovès Egyptas. Nacionalinis MK Čiurlionio dailès muzjeius. Kaunas.

17 Villa C., Lynnerup N. (2012). Hounsfield units ranges in CT-scans of bog bodies and mummies. Anthrop Anz, 69(2), 127-145.

18 Wade A.D., Nelson A.J. (2013). Radiological evaluation of the evisceration tradition in ancient Egyptian mummies. Homo, 64(1), 1-28.

\section{Address for correspondence:}

Dr Dario Piombino-Mascali

Department of Anatomy, Histology and Anthropology

Faculty of Medicine, Vilnius University

MK Čiurlionis street 21, LT-03101, Vilnius, Lithuania

E-mail: dario.piombino@mf.vu.lt 